\title{
Probing theoretically into Central and Eastern Europe: transactions, resources, and institutions
}

\author{
Klaus E Meyer ${ }^{1}$ and \\ Mike W Peng ${ }^{2}$ \\ ${ }^{1}$ University of Reading, Reading, Berkshire, UK; \\ ${ }^{2}$ University of Texas at Dallas, Richardson, \\ Texas, USA \\ Correspondence: \\ Klaus E Meyer, University of Reading, \\ Whiteknights, PO Box 217, \\ Reading, Berkshire RG6 6AH, UK \\ Tel: + 44 (0) 118378 6034; \\ Fax: + 44 (0) 1183786305 \\ E-mail: k.meyer@rdg.ac.uk
}

\begin{abstract}
Since the 1990s, Central and Eastern Europe (CEE) has provided unique societal quasi-experiments, which represent opportunities to test the applicability of existing theories in international business and management studies and to develop new ones. Specifically, three lines of theorising have been advanced: (1) organisational economics theories; (2) resource-based theories; and (3) institutional theories. For each of these theories, we discuss how they contribute to the understanding of key issues, such as entry strategies of foreign investors, restructuring strategies of local incumbents, and entry and growth strategies of entrepreneurs. On this basis, we assess how CEE research has influenced the overall trajectories of theory development. CEE research has in particular highlighted the importance of contextual influences such as institutions. Thus, scholars have aimed at incorporating institutions into theories (such as organisational economics theories and resource based theories) and advancing an institution-based view of business strategy as a complementary perspective. We outline how future research in CEE and other emerging economies may advance this research agenda further.

Journal of International Business Studies (2005) 36, 600-621.

doi: 10.1057/palgrave.jibs.8400167
\end{abstract}

Keywords: international business theory; Central and Eastern Europe; transaction cost theory; resource-based theory; institutional theory

\section{Introduction}

At the core of contemporary research in international business (IB) and management lies the development of alternative theoretical perspectives. New phenomena of interest permit new applications for existing theories, as well as the advancement of modified or new theories. Therefore, new phenomena present a fascinating research laboratory in which to assess the explanatory and predictive power of different theories. As scholarly interests in the transition economies of Central and Eastern Europe (CEE) ${ }^{1}$ have expanded significantly since the late 1980s (Peng, 2000; Meyer, 2001a), these interests have started to assert influence on broader theory development (Zahra et al., 2000).

CEE provides an interesting laboratory for developing and testing theories, because the transition processes provide a series of unique societal quasi-experiments. Even among emerging economies, CEE is special owing to the radical switch from central planning to 
market competition and the high degree of industrialisation (Svejnar, 2002). Thus, businesses face challenges of managing radical strategic and organisational changes rather than traditional issues of economic development such as moving from an agricultural society to an industrialised economy. These societal quasi-experiments allow scholars to test the generalisability of existing theories and to identify hidden features and assumptions that are often unnoticed when conducting research in mature market economies. Recently, Peng (2001b, 2006), Werner (2002) and $\mathrm{Lu}$ (2003) have surveyed the general IB and management literature. However, their global coverage does not allow for a focus on issues that are particular to any specific region, such as CEE. Given that much research is pursued on a region-by-region basis, we assess the interaction between research on one key region - CEE - and the larger literature. Key questions we address are:

(1) What theories have emerged as leading perspectives underpinning IB and management research focusing on CEE?

(2) More importantly, how does research on CEE contribute to general theory development beyond CEE?

Addressing these two questions, we suggest that three sets of theories - organisational economics theories (namely, transaction cost theory (TCT) and agency theory (AT)), resource-based theories (RBTs), and institutional theories (ITs) - have emerged as leading foundations underpinning CEE research. When reviewing research on emerging economies, Hoskisson et al. (2000) and Wright et al. (2005) identify these theories as the leading perspectives, a proposition with which we concur. ${ }^{2}$

Among numerous theories, why have TCT/AT, RBTs and ITs emerged as leading perspectives? McKinley et al. (1999) argue that whether a particular theory gains widespread acceptance depends on its continuity, novelty, and scope. In CEE research, organisational economics theories probably display the highest degree of continuity, because they are basically applied to a new setting. RBTs also display some continuity, by drawing on existing work developed elsewhere. ITs, as employed in CEE, seem to have a relatively low degree of continuity, by pushing factors usually considered as 'background' in IB and management research to the 'front stage' (Ingram and Silverman, 2002). On the other hand, ITs offer the highest degree of novelty, in this highly unusual and novel context (Peng, 2003).
Whereas TCT and AT were relatively well established before CEE's transitions, RBTs and ITs represent more recent theoretical developments, whose emergence approximately coincides with the rising scholarly interests in CEE. We further argue that CEE research has significantly propelled the development of these theories, with varying degrees of impact. The main challenge that CEE scholars have struggled with is how to incorporate the specific contextual influences into their theoretical reasoning. Some studies aim to incorporate contextual variables, notably institutions and radical environmental change, into existing theories, such as TCT/AT or RBTs, whereas others aim to advance an institution-based view of business strategy. CEE research has thus significantly pushed the frontier of ITs.

In the remainder of this article, we outline strategic issues faced by the three main organisational domains that have attracted substantial research attention (Peng, 2000; Meyer, 2001a):

(1) foreign entrants;

(2) local incumbents; and

(3) local start-ups.

To investigate the impact of CEE research, we have built a database of CEE-related articles in top journals, and have analysed contributors and citations (see Appendix A). This database is the main basis of our article, with an emphasis on the most cited and presumably most influential contributions. We conclude by outlining an agenda for future theoretical and empirical research in CEE and other emerging economies.

\section{Key research issues}

To investigate the contributions of CEE research to the broader research agenda in the field, we focus on the key issues confronting three different types of firm (Table 1):

(1) Foreign entrants. CEE research has focused on the motives and entry strategies of foreign entrants (Brouthers et al., 1999; Fahy et al., 2000; Meyer, 2001b; Brouthers and Brouthers, 2003). In parallel, researchers have analysed challenges facing entrants after the initial entry, such as knowledge transfer in joint ventures (JVs) (Lyles and Baird, 1994; Lane et al., 2001), cross-cultural management in foreign-owned businesses (Child and Markóczy, 1993; Elenkov, 1998; Fey and Björkman, 2001; Michailova, 2002), and 


\section{Multinational Enterprises and Emerging Economies}

谊 602 Probing theoretically into Central and Eastern Europe Klaus E Meyer and Mike W Peng

Table 1 Leading theories, organisational domains, and representative studies ${ }^{a}$

\begin{tabular}{|c|c|c|c|}
\hline Theories & Foreign investors' entry strategies & $\begin{array}{l}\text { Local incumbents' restructuring } \\
\text { strategies }\end{array}$ & $\begin{array}{l}\text { Entrepreneurs' entry and growth } \\
\text { strategies }\end{array}$ \\
\hline $\begin{array}{l}\text { Transaction cost/agency } \\
\text { theory }\end{array}$ & $\begin{array}{l}\text { Brouthers et al. (1999) } \\
\text { Meyer }(2001 \mathrm{~b})^{\mathrm{b}} \\
\text { Nakos and Brouthers }(2002) \\
\text { Brouthers and Brouthers }(2003)^{\mathrm{b}}\end{array}$ & $\begin{array}{l}\text { Buck et al. (1998) } \\
\text { Filatotchev et al. }(2000,2003)^{b} \\
\text { Peng et al. (2003) }\end{array}$ & No studies identified \\
\hline Institutional theories & $\begin{array}{l}\text { Child and Markóczy }(1993)^{\mathrm{d}} \\
\text { Brouthers and Bamossy (1997) } \\
\text { Bridgewater (1999) }^{\mathrm{d}} \\
\text { Buck et al. }(2000)^{\mathrm{f}} \\
\text { Fey and Björkman (2001) } \\
\text { Brouthers and Brouthers (2001) } \\
\text { Michailova (2002) } \\
\text { Meyer (2002) }\end{array}$ & $\begin{array}{l}\text { Carroll et al. (1988) } \\
\text { Welsh et al. (1993) } \\
\text { Luthans et al. (1993) } \\
\text { Puffer (1994) }{ }^{\text {d }} \\
\text { Frese et al. (1996) } \\
\text { Peng and Heath (1996) } \\
\text { Whitley et al. (1996) } \\
\text { Ralston et al. (1997) } \\
\text { Whitley and Csaban (1998) } \\
\text { Mueller and Clarke (1998) } \\
\text { Weber and Hsee (1998) } \\
\text { May et al. (2000) } \\
\text { Pearce et al. (2000) } \\
\text { Makhija and Stewart (2002) } \\
\text { White and Linden (2002) } \\
\text { Buck (2003) } \\
\text { Peng (2003) } \\
\text { Csaban et al. (2003) }\end{array}$ & $\begin{array}{l}\text { McCarthy et al. (1997) } \\
\text { Peng (2001a) } \\
\text { Ardichvili and Gasparishvili (2003) }\end{array}$ \\
\hline
\end{tabular}

${ }^{\mathrm{a}}$ The listed studies are representative ones. This table is not an exhaustive list of relevant articles. ${ }^{\text {b} A l s o ~ d r a w s ~ u p o n ~ I T s . ~}$

${ }^{c}$ Covers both local incumbents and start-ups.

${ }^{\mathrm{d}}$ Also draws upon TCs.

eAlso draws upon RBTs.

${ }^{f}$ Covers both foreign and local firms.

postacquisition restructuring (Meyer and Estrin 2001; Meyer and Lieb-Dóczy, 2003).

(2) Local incumbents (including state-owned enterprises (SOEs) and privatised firms). Research on local incumbents has primarily been concerned with the challenges associated with restructuring (Newman, 2000; Uhlenbruck et al., 2003) and its antecedents, including governance structures (Filatotchev et al., 1996, 2000; Buck et al., 1998) and business cultures (Welsh et al.,
1993; Puffer and McCarthy, 1995; Frese et al. 1996).

(3) Newly established local firms. Entrepreneurship is a relatively new phenomenon in CEE - so is entrepreneurship research on CEE (Peng, 2001a; Estrin et al., 2005). Only recently have scholars begun to analyse the determinants of new firm establishment (Puffer and McCarthy, 2001; Batjargal, 2003) and their survival (Lyles et al., 2004). 
The following three sections review the contributions and challenges for research related to each of the three sets of theories (TCT/AT, RBTs and ITs), by using the three strategic challenges as testing stones to assess the contributions of CEE research. In other words, we focus on eight of the nine cells outlined in Table 1 (one cell remains empty, as no study on entrepreneurial strategies has drawn on TCT or AT).

\section{Organisational economics theories}

\section{Organisational economics theories in a transition context}

Organisational economics theories such as TCT and AT have been developed with an assumption of relatively static, well-developed market mechanisms. In a different institutional framework, where such an assumption may not hold, it is not surprising that scholars applying these two theories encounter formidable challenges. Williamson (1991) has acknowledged these challenges and proposed that differences in institutions can be conceived as 'shift parameters' that alter the slope or intercept of transaction costs (TCs). Yet this approach, which implies that the institutional differences are simple control variables, ignores the potential value in exploiting institutional variation to better understand the nuances and limitations of TCT. In the transition context, TCs are particularly high owing to the 'weak institutions' and high uncertainty. For example, the lack of information systems and effective courts raised search and monitoring costs, and constraints on opportunistic behaviour may become ineffective (Swaan, 1997). Yet scholars find it difficult to measure the pertinent TCs with the necessary methodological rigour. This is a general problem of TCT research (Boerner and Macher, 2004), but it becomes particularly relevant in CEE. The proxies that signify a rise in TCs in Western studies may be of limited use because the drivers of TCs are different. For example, TCT research associates intangible assets with market failure, yet in transition economies markets for tangible assets, such as real estate, are also subject to high TCs (Estrin et al., 1997). Thus, to be able to develop new proxies, scholars need to attain a deeper understanding of what drives TCs in transition economies (Table 2).

AT posits that although managers as agents are theoretically expected to comply with the interests of enterprise owners as principals, in reality it is difficult for owners to ensure that managers actually comply (Jensen and Meckling, 1976). When applying this line of thought to CEE, researchers encounter similar problems of defining the basic constructs because agency relationships are complex and vaguely defined, especially in recently privatised enterprises (Filatotchev et al., 1996; McCarthy and Puffer, 2003). Straightforward application of traditional AT models yields limited predictive power (Peng et al., 2003). Thus, meaningful predictions on the linkage between governance structures and corporate performance require careful consideration of the formal governance structures as well as informal lines of authority and the associated role and power of various stakeholders, including board members and employees (Buck et al., 1998).

\section{Foreign investors' entry strategies}

The TCT analysis of entry strategy essentially argues that a decision over governance mechanisms, such as entry mode choice, requires a rational trade-off

Table 2 CEE issues associated with transaction cost economics and agency theory

\begin{tabular}{|c|c|c|}
\hline Challenge to theory & Implications & Methodological challenges \\
\hline $\begin{array}{l}\text { TCs are very high due to } \\
\text { 'weak' institutions and } \\
\text { high uncertainty }\end{array}$ & $\begin{array}{l}\text { Relative to developed economies, TCs } \\
\text { are even harder to measure in CEE, which } \\
\text { lowers predictive power of the theory }\end{array}$ & $\begin{array}{l}\text { Need for better direct and/or indirect } \\
\text { measures, that is, what contextual influences } \\
\text { drive TCs? }\end{array}$ \\
\hline $\begin{array}{l}\text { TCs vary across markets, } \\
\text { in different ways than in } \\
\text { mature market economies }\end{array}$ & $\begin{array}{l}\text { Need to identify which TCs are of particular } \\
\text { concern to which types of business } \\
\text { transactions }\end{array}$ & $\begin{array}{l}\text { Need to measure TCs across countries, } \\
\text { industries and industry-segments within } \\
\text { the region }\end{array}$ \\
\hline $\begin{array}{l}\text { Agency relationships are } \\
\text { complex and vaguely } \\
\text { defined }\end{array}$ & $\begin{array}{l}\text { Relationships are hard to model and } \\
\text { predictive power of conventional models } \\
\text { is weak }\end{array}$ & $\begin{array}{l}\text { Need to capture both formal and informal } \\
\text { sources of power governing principal-agent } \\
\text { relationships }\end{array}$ \\
\hline
\end{tabular}


between the TCs associated with market and with hierarchy modes (Anderson and Gatignon, 1986; Hennart, 1988). As TCs are moderated by the peculiarities of the institutional environment, scholars applying TCT to explain the choice of organisational forms in CEE often integrate institutions in their TCT reasoning. For example, Meyer (2001b) follows North (1990) in arguing that institutions shape TCs, which in turn determine investors' internalisation decisions. Building on Oxley's (1999) TCT-based work on intellectual property rights and FDI, Meyer (2001b) proxies institutional development with transition indicators of the European Bank for Reconstruction and Development (EBRD), and finds that lower TCs of establishing local operations make it more likely that foreign investors will establish wholly owned operations rather than JVs or contractual cooperation. Thus, TCs of establishment, which at the time notably included negotiations with privatisation agencies (Brouthers and Bamossy, 1997), were a stronger deterrent than the potentially high coordination costs in JVs. Brouthers and Brouthers (2003) focus on the impact of TCs associated with environmental and behavioural uncertainty on entry mode decisions. They find that full ownership is inhibited by behavioural uncertainty in the case of (people-intensive) service FDI, but by environmental uncertainty for (capital-intensive) manufacturing FDI. ${ }^{3}$

Other studies explore how high TCs may deter FDI altogether. Bevan et al. (2004) proxy TCs by the same EBRD indicators as Meyer (2001b), but in a disaggregated form, and find that some aspects such as foreign trade liberalisation significantly facilitate the inflow of FDI, whereas others such as domestic price liberalisation would not. Javorcik (2004) finds that weak intellectual property rights (and thus high enforcement costs) deter FDI in high technology sectors, but do not deter FDI in sales and distribution.

Overall, this research provides a finer-grained understanding of which forms of institutional shortcomings are most likely to raise TCs of concern to foreign investors. Thus, TCT-based research in CEE has redirected its focus from firmspecific variables indicating sensitivity to TCs to contextual variables that moderate TCs in specific markets.

However, relatively few studies on foreign entrants apply TCT as their main theoretical base (Table 1). This may be a function of the relative maturity stage of TCT, whereby pure applications of
TCT, whether in CEE or elsewhere, may be difficult to publish given the crowded TCT literature (Boerner and Macher, 2004). In part, this may also be because many of the unique features that make economic transitions an interesting social quasi-experiment are change processes, and TCT as a substantively static theory has relatively less to contribute to analysing dynamic processes. However, we see potential for further development of TCT through more rigorous testing of propositions concerning the link between institutions, TCs, and FDI inflows (Javorcik, 2004) or MNE's entry modes (Meyer, 2001b). Moreover, the transition context provides opportunities to drill down further nuances of the TC parameters by exploiting the regional variation across and within countries.

\section{Incumbent's restructuring strategies}

In CEE, AT has not only served as an analytical tool but has also informed key political decisions in the reform process. A key deficiency of the socialist enterprise has been the lack of private ownership and consequently weak incentives for managers to improve firm performance. Privatisation has aimed at creating appropriate principal-agent relationships that would induce managers to optimise firm performance under the guidance and monitoring of new owners (Boycko et al., 1995). Yet, among the many alternative methods of privatisation employed in the region, many did not lead to new governance structures that would meet this expectation (Djankov and Murrell, 2002; Estrin, 2002).

CEE research on privatisation is a large part of the rapidly growing global literature mostly published in economics (Megginson and Netter, 2001). In a review, Estrin $(2002,101)$ finds that

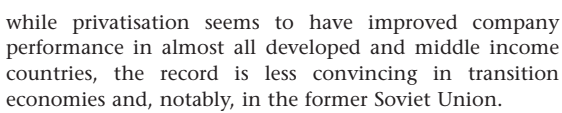

In a meta-analysis, Djankov and Murrell (2002) find that privatisation tends to have a positive impact on performance; yet, contrary to AT predictions, ownership explains only a small part of the variation in performance. Tentatively, both Estrin (2002) and Djankov and Murrell (2002) attribute the poorer performance in countries such as Russia to the weaker institutional development. 
The IB and management literature finds similarly ambiguous results on the impact of ownership change on firm performance in CEE. Although some firms engaged in strategic restructuring following privatisation (Filatotchev et al., 2001), many domestically owned CEE firms did not fundamentally change their strategies or structures (Whitley and Csaban, 1998; Newman, 2000). The only group of firms that is consistently reported to change strategies and improve performance comprises firms privatised by sale to foreign investors (Uhlenbruck and De Castro, 2000). Moreover, the influence of specific agents normally associated with improved governance and thus improved performance, such as outside board members (Peng et al., 2003) or institutional investors (Belev, 2003), does not appear to have a significantly positive effect on firm performance. These outcomes contrast with the predictions of AT and the expectations of those who designed the privatisation programmes.

What accounts for these apparent failures of AT to predict linkages among ownership, governance, and performance? Apparently, principal-agent relationships and power structures are different from what outside observers, such as Western scholars, presume them to be. Often agency relationships in privatised firms are defined only vaguely, thus giving managers considerable de facto autonomy. Even if governance structures are well defined at corporate level, their effectiveness may be hampered by weaknesses in background institutions such as law and contract enforcement in the country (Buck et al., 1998).

The lack of support for the link between ownership and corporate performance has stimulated in particular two lines of research:

(1) How can systems of governance be improved in order to increase the effectiveness corporate governance?

(2) How are postacquisition privatised firms actually governed?

First, it is now widely recognised that privatisation in itself is insufficient, and that the creation of effective systems of governance is necessary to improve enterprise performance (Djankov and Murrell, 2002; Estrin, 2002; McCarthy and Puffer 2003). While privatisation, if done right, may improve performance, such right conditions primarily centre on institutional contexts and policies. The key is the construction of appropriate governance structures, which in turn is a challenge to institution-building.
Thus, the gradual evolution of ownership patterns toward more outside owners and more ownership concentration (Jones and Mygind, 1999) may improve governance in the long term. However, the institutions that shape corporate governance are grounded in the history of societies, as shown by Buck (2003) for Russia. The introduction of new and coherent formal systems of governance is a time-consuming process. Before the arrival of these systems, it is likely that informal mechanisms of control, monitoring and contract enforcement are being used during the transition. Future research may thus pay more attention to informal mechanisms.

The second line of research aims for finer-grained analysis of governance structures to explore the actual autonomy of managers and the influence of stakeholders other than shareholders. In contrast to a straightforward set of principal-agent relationships as portrayed by AT, a wide range of stakeholders such as employees and government authorities have de facto influence on corporate decisions in CEE (Buck et al., 1998; Mygind, 2001; McCarthy and Puffer, 2003). Thus, a key challenge for governance research is to develop theoretical tools to analyse the influence of the relevant institutions, hierarchies, stakeholders, and control mechanisms in privatised enterprises (Buck et al., 1998), and to explain how organisational leaders can effectively transform their enterprise under such circumstances (Meyer, 2004).

\section{Evaluation of theory application and development}

CEE research has pointed out the limitations of organisational economics theories in a complex, volatile, and highly uncertain environment. Developed in a relatively stable Western environment, TCT assumes availability of alternative modes and identifiable (though not necessarily measurable) TCs, and AT assumes clearly defined and stable agency relations. However, these assumptions may not hold in CEE (Table 2). Dynamic models based on TCE, such as switching costs of foreign investment modes (Benito et al., 1999) or adjustment costs of organisational change (Nickerson and Silverman, 2003), have not yet been applied in CEE.

Organisational economists have applied their theories in CEE mainly by incorporating elements of institutions. In CEE, transaction and agency costs may vary less with the characteristics of the firms, but more across countries and industries. IB 
research has traditionally focused on firm-specific variables to assert which firm would prefer which organisational arrangement. Yet CEE research has redirected attention to institutions moderating TCs to analyse how organisational arrangements vary across contexts. This focus on the link between TCs and institutions is arguably a back-to-the-roots movement, as both TCT and AT have historically been classified as part of the 'new institutionalism' (North, 1990; Williamson, 2000). However, these theories have yet to be shown to yield deep insights into dynamic processes such as radical organisational change.

\section{Resource-based theories}

RBTs in a transition context

RBTs focus on idiosyncratic resources and capabilities as drivers of firm performance, and have significantly influenced recent IB literature (Peng, 2001b). In this discussion of RBTs, we include not only Barney's (1991) resource-based view of the firm, but also related theories such as organisational learning theories (Fiol and Lyles, 1985), evolutionary theories (Kogut and Zander, 1993), and dynamic capabilities views (Teece et al., 1997) hence our use of the plural form 'resource-based theories'. CEE research has significantly broadened and deepened the RBT literature, while raising new puzzles and questions. Key challenges for applying RBTs arise from the need to identify which resources constitute a basis for competitive advantage in a transition context. While the basic VRIO criteria - value, rarity, imitability and organisation (Barney, 1991) - would apply in theory, the types of actual resources that fulfil these criteria are different. For example, in a highly idiosyncratic environment, context-specific resources such as business networks (Peng and Heath, 1996) and processrelated capabilities such as strategic flexibility (Uhlenbruck et al., 2003) may be important.

The context thus influences the way firms manage their resources. Processes of developing, transferring and exploiting resources vary in a transition context, which calls for new measures to capture these dynamics. Change processes are often gradual and interdependent, but occasionally radical and discontinuous. The transition economies experienced numerous incidences of discontinuous change that are less well explained by existing theories. Moreover, the perceived organisational fit between organisations may be spurious if only traditional measures of fit are used (Table 3 ). These challenges to theories affect the analysis of the strategies of the three types of business reviewed in this article.

\section{Foreign investors' entry strategies}

RBTs have been applied to analyse how foreign entrants can manage their JVs with, or acquisitions of, local firms, including issues such as partner selection, organisational learning, and postacquisi-

Table 3 CEE issues associated with resource-based theories

\begin{tabular}{|c|c|c|}
\hline Challenge to theory & Implications & Methodological challenges \\
\hline $\begin{array}{l}\text { Foreigners (investors, scholars) may face } \\
\text { obstacles in recognising the idiosyncratic } \\
\text { qualities and importance of resources in } \\
\text { an unfamiliar context }\end{array}$ & $\begin{array}{l}\text { Lack of understanding of the context } \\
\text { inhibits the analysis of resources, such } \\
\text { that, for instance, perceptions of } \\
\text { organisational fit may be spurious }\end{array}$ & $\begin{array}{l}\text { Identification and measurement of key } \\
\text { resources needs to incorporate the } \\
\text { context }\end{array}$ \\
\hline $\begin{array}{l}\text { Contextual conditions moderate processes } \\
\text { of developing, transferring, and exploiting } \\
\text { resources }\end{array}$ & $\begin{array}{l}\text { Acquisition of tacit knowledge from other } \\
\text { organisations such as foreign partners, } \\
\text { catch-up, organisational learning, } \\
\text { 'unlearning' old routines }\end{array}$ & $\begin{array}{l}\text { Need for new models and theories } \\
\text { to capture these processes under } \\
\text { consideration of contextual variables }\end{array}$ \\
\hline
\end{tabular}


tion restructuring. However, researchers face major challenges in identifying the resources and change processes that create value in the specific context.

Complementarity of resources is believed to be crucial for the success of JVs and acquisitions, yet what resources are complementary? In a rapidly changing environment, local firms need to reconfigure their resources. Thus, they are interested in using alliances with MNEs to outcompete their local rivals (Fahy et al., 2000), and they seek partners with financial assets, technical capabilities, and marketing savvy (Hitt et al., 2000, 2004). On the other hand, foreign investors seek primarily local partners that help them to gain access to local markets (Hitt et al., 2000). They would thus seek local resources such as brands and distribution channels, as well as partners that are capable of receiving and adopting transferred production technology. Beyond the specific country, MNEs may also seek region-specific capabilities, such as local firms' existing export relationships in CEE beyond their home country. Yet, Uhlenbruck (2004) finds, surprisingly, that acquirers on average do not benefit from these resources, as target firms' export market position in other CEE countries does not seem to enhance performance.

A good organisational fit between two acquiring and target firms is usually regarded as a key aspect of complementarity. Yet, a puzzle has emerged. Surprisingly, Uhlenbruck and De Castro (2000) find that the higher the degree of organisational fit between SOE targets in CEE and their Western acquirers (e.g., both focusing on control and reward systems), the worse the postacquisition performance. Uhlenbruck and De Castro (2000: 393) speculate that, given the different institutional contexts, 'an appearance of organisational fit may be illusory'. However, they cannot ascertain how and why seeming organisational fit can lead to a negative impact on postacquisition performance. This result is probably due to the lack of attention of Western MNEs on these areas (e.g., control and reward systems) whereby there is some seeming 'fit'; in reality, these areas probably should have been changed as much as other areas without such fit. Thus, the assessment of partners' resources has to pay careful attention to contextual variables, and adopt selection criteria and analytical instruments accordingly. More generally, these findings point to the hazards of applying measures of organisational resources, such as fit, that have been validated by research in the West, to another context.
Several studies point out that to make a JV or an acquisition work in CEE often requires massive resource transfers from the foreign parent, and additional resource transfers from the foreign parent are a major determinant of business performance (Uhlenbruck and De Castro, 2000). Strong foreign parent support is also identified as a resource critical for JV success, although imbalanced resource contributions may lead to imbalanced management control, which in turn may be harmful for performance (Steensma and Lyles, 2000). The need for new financial and managerial resources has led to many acquisitions where foreign partners transfer more additional resources to the new venture than those contributed by local firms, such that the local operations are entirely transformed. Thus, acquisitions after only a few years may resemble greenfield projects - a phenomenon called 'brownfield' (Meyer and Estrin, 2001).

A major stream of research investigates how foreign investors can facilitate organisational learning in JVs and acquired firms in CEE. This line of work is exemplified by a series of studies focusing on JVs in Hungary by Lyles and co-authors (Lyles and Salk, 1996; Steensma and Lyles, 2000; Lane et al., 2001; Dhanaraj et al., 2004). Their findings support a core RBT assertion that capabilities to learn from partners are tacit resources underlying the competitive advantage of a firm, or a JV in this case. In particular, these studies focus on how market-based capabilities can be transferred from MNE parents and learned by the JVs. Such learning not only entails absorbing new ways of doing business but also requires some 'unlearning' of existing routines not conducive under the new circumstances. Lane et al. (2001) present a differentiated concept of absorptive capacity in JVs, and test its impact on learning and performance. They find that some aspects influence learning as predicted, whereas other aspects, surprisingly, do not influence learning, but benefit performance directly.

Recently, Dhanaraj et al. (2004) have investigated how relational embeddedness impacts on the transfer of explicit and implicit knowledge. They find that tacit knowledge transfer is influenced by three proxies for embeddedness: trust, shared systems, and parent-JV tie strength. Distinguishing between young and mature JVs, they report that all three variables are significant for mature JVs, but the tie strength is not significant for young JVs. In contrast, explicit knowledge transfer is not dependent on relational embeddedness for mature JVs, 
yet for young JVs tie strength and shared systems matter. This study thus provides detailed insights into relational embeddedness as a resource enhancing JV knowledge transfer and thus performance. Further research into the concepts of absorptive capacity (e.g., Minbaeva et al., 2003) and relational embeddedness may enhance our understanding of what resources enable organisations to receive, adopt, and apply external knowledge.

Also, broader research questions merit attention. First, which locally held resources induce foreign investors to acquire a firm even though they have to engage in costly deep restructuring and invest considerable additional resources to create a competitive entity? Second, how can acquirers manage the massive restructuring in brownfield acquisitions (Meyer and Estrin, 2001) without falling into the traps of imbalanced managerial control (Steensma and Lyles, 2000) or alienation of the indigenous managers and employees? The integration may be complicated by large differences in organisational cultures, structures and processes, especially in acquisitions related to privatisation (Uhlenbruck and De Castro, 1998; Meyer, 2002). Some authors thus emphasise the need to move cautiously so as to retain, activate and develop latent local resources (Michailova, 2002; Meyer and Lieb-Dóczy, 2003), whereas others show how radical change can be successful (Blaszejewski and Dorow, 2003). Overall, although the need for extensive knowledge transfer and deep restructuring is widely acknowledged, the empirical verdict on the merits of alternative postentry strategies is still out.

\section{Incumbent's restructuring strategies}

RBT research has addressed two aspects of the restructuring of former SOEs:

(1) To what extent can inherited resources provide a basis for competitiveness under changed circumstances?

(2) How can firms reorganise and enhance their resources in order to become market competitive?

On the first issue, research suggests that contrary to common perceptions - inherited resources may be important for success in the transition. For example, in the Czech Republic, Makhija (2003) demonstrates that, under conditions of radical environmental change, firms' resource endowment provides better predictors of corporate performance than conventional indus- trial organisation variables. Although many studies document the lack of critical resources in CEE firms, it is important to note that some firms have been relatively well endowed. The East German Zeiss in Jena, for instance, has developed distinct capabilities and a moderately successful export record (Kogut and Zander, 2000). Likewise, some East German symphony orchestras are found to be relatively successful at adaptation, which is due to 'a joint function of an orchestra's prior strength ... and the kinds of leadership initiatives taken by orchestra leaders and players [during the transition]' (Allmendinger and Hackman, 1996, 337). Among inherited resources, this study points to an important resource to which the CEE literature has surprisingly not paid much attention: leadership (for exceptions see Fey et al., 2001; Elenkov, 2002).

Even if inherited resources are of potential value, they have to be reorganised. However, early restructuring strategies following standard Western advice did not seem to succeed. Surprisingly, asset restructuring with reduction of the typically high degree of diversification of postsocialist enterprises on average reduced the performance of firms in the Czech Republic (Spicer et al., 2000; Makhija, 2004). Arguably, many Western advisers lacked an in-depth understanding of how indigenous resources can be put to best use in the transition context.

RBTs focus on the properties of resources and capabilities that may enable firms to regain competitiveness, such as the ability of an organisation to learn and to change flexibly. Newman (2000), based on case research in the Czech Republic, analyses the internal processes of learning and transformation and argues that, with weak absorptive capacity, a very big learning gap may actually inhibit organisational change. Notably, the cognitive ability of managers and employees to envisage major change and to identify and implement radically different routines is limited. In consequence, the relationship between the extent of organisational change and the gap between actual and aspired performance takes actually an inverse-U-shaped form: if environmental change is too radical, organisations may be paralysed rather than striving to adapt. Newman's (2000) argument is taken one step further by Uhlenbruck et al. (2003), who posit that internal consistency and strategic flexibility are key to successful change process.

Scholars taking an evolutionary perspective consider the observed continuity as natural (Whitley 
and Csaban, 1998). When facing change - even radical change - in their environment, organisations evolve, rather than reincarnate themselves overnight. Consequently, Spicer et al. (2000) suggest that radical privatisation broke up existing industry networks and thus inhibited the effective use of cospecialised resources. Overall, an emerging contribution out of CEE research seems to refute what may be called the 'Lego' view of the firm, in which firms can be assembled from modules of resources (à la Lego toy blocks), taken out from CEE firms, and imported from the West. Much of the organisational economics literature implicitly assumes that resources ('factors of production' in the economics terminology) can be (re)combined in varying proportions such as to optimise a production function. However, studies analysing enterprise transformation with an evolutionary perspective (Spicer et al., 2000; Meyer and LiebDóczy, 2003) emphasise that the feasibility of alternative combinations of resources is path dependent because old knowledge and routines are to some degree 'sticky', and that organisational change may require significant efforts of 'unlearning' before firms can embark on successful new learning (Newman, 2000).

Thus, RBTs may be more suitable than organisational economics theories to analyse change processes. The research on organisational change in CEE illustrates that indigenous resources may be a source of value creation even in a fundamentally changed environment. Yet, they require major reconfiguration, and RBTs illuminate the processes by which such resources are acquired, adopted, and exploited. However, this research needs to be taken further, and RBTs ought to incorporate contextual variables more explicitly in the theoretical reasoning.

\section{Entrepreneurs' entry and growth strategies}

The importance of new firm creation for economic transition and growth is widely acknowledged (Peng, 2001a; McMillan and Woodruff, 2002; Estrin et al., 2005), yet entrepreneurship is still a very young field of research in CEE. Although the transition may have opened opportunities for entrepreneurship throughout the region, the actual number of people engaged in entrepreneurial activity is lower in CEE than in countries at similar levels of income. In the index of total entrepreneurial activity, Russia ranked as the second lowest among 47 countries surveyed in the
Global Entrepreneurship Monitor 2002 (Reynolds et al., 2002).

RBTs focus on the resources that entrepreneurs can draw upon to explain why CEE countries are relatively weak in developing new firms. Perhaps the single most important driver of start-ups' resourcefulness lies in their founding entrepreneurs (Peng, 2001a; Puffer and McCarthy, 2001). As entrepreneurship inevitably implies some deviation from average behaviour in any given population, some entrepreneurial traits (e.g., a strong achievement orientation, a strong locus of control, and a high risk-taking propensity) seem to transcend cultural values and are found in many countries (Peng, 2000).

Beyond their own resourcefulness, entrepreneurs would have to access complementary resources including human and financial capital. Thus, they would have to be able to employ people and raise capital, which under conditions of imperfect markets is difficult (McMillan and Woodruff, 2002; Estrin et al., 2005; Kriauciunas, 2006). Batjargal (2003) investigates the impact of various aspects of networks for small firm performance in Russia, and finds that, in particular, weak ties and the resourcefulness of network contacts enhance revenue growth.

The question of whether entrepreneurs have access to suitable complementary resources arises in particular when they focus on international markets. An interesting finding is that, according to a study in Hungary, local start-ups, if they internationalise aggressively, end up having a lower likelihood of survival (Lyles et al., 2004). This may be at odds with the advice for CEE firms to seek export markets to counter-balance the lack of domestic demand during the transition. However, firms have to build appropriate resources before internationalising, and this study is a cautionary reminder of the risks of premature overseas ventures for local start-ups.

These are interesting observations in singlecountry studies, but we still lack systematic studies comparing the profiles of large samples of entrepreneurs in CEE with those elsewhere. The processes of resource accumulation and exploitation by entrepreneurs during the transition are not well understood. First steps have been made to explore both the personality traits of entrepreneurs and the resources that they are able to access. RBTs may guide further research to deepen our understanding of entrepreneurship in highly imperfect markets. 
Evaluation of theory application and development While generally supporting RBT assertions, CEE research has also encountered some new puzzles and raised new questions. In particular, CEE research highlights a previously overlooked aspect: the types of resources creating and sustaining competitive advantage vary across contexts both cross-sectionally (such as developed $v s$ transition economies, and Central Europe vs former Soviet Union) and longitudinally (such as during the central planning era $v s$ during the transition era). Although inherited resources may still be valuable, many local firms do not possess many of the normal resources of Western businesses. Thus, at least initially, adaptation of existing resources and development of new resources are crucial.

In different contexts, competitive advantages are gained on the basis of different resources, especially with respect to capabilities grounded in human capital. For instance, top management and leadership skills, as well as organisational culture, may vary considerably across institutional contexts. Future research ought to investigate these variations, and link contextual variables such as local institutions with the processes of resource development and exploitation. Moreover, researchers may investigate further how institutional environments modify internal resource reconfiguration processes and integrate this link into rigorous theoretical reasoning and empirical analysis, possibly by incorporating RBTs and ITs (Filatotchev et al., 2003).

\section{Institutional theories}

Institutional theories in a transition context

Since the 1980s, ITs have become a major perspective in the social sciences. Institutions are typically defined as the 'rules of the game in a society' (North, 1990, 3), which include formal rules (laws and regulations) and informal constraints (customs, norms, and cultures). ${ }^{4}$ The core claim of ITs is that 'actors pursue their interests within institutional constraints' (Ingram and Silverman, 2002 , 1). Although, on the surface, this proposition does not sound ground-breaking, its value becomes more evident when one appreciates the historical neglect of institutions in much of IB and management research (until recently). Developed primarily in mature market economies, TCT, AT and RBTs model firms and markets independently of environmental peculiarities. As a result, important institutional factors influencing such markets (e.g., regulations and norms) have often been taken for granted by IB and management researchers.

In contrast, CEE researchers increasingly realise that institutions are much more than background conditions, and that 'institutions directly determine what arrows a firm has in its quiver as it struggles to formulate and implement strategy and to create competitive advantage' (Ingram and Silverman, 2002, 20, added italics; see also Carroll et al., 1988). The institutional transitions sweeping CEE, defined as 'fundamental and comprehensive changes introduced to the formal and informal rules of the game that affect organizations as players' (Peng, 2003, 275), highlight the value of ITs and also the hazard of failing to appreciate the institutional forces. As a result, CEE research, which coincided with the emergence of IT research in IB and management in general in the 1990s, has played a major role behind the rising influence of this perspective.

\section{Foreign investors' entry strategies}

Institutional differences are particularly noted by MNEs operating in multiple institutional contexts. Formal rules establish the permissible range of entry strategies (e.g., with respect to equity ownership) and set the stage for possible bargaining between investors and authorities (Brouthers and Bamossy, 1997; Henisz, 2000; Ramamurti, 2001). Moreover, crucial in CEE, informal institutions such as managerial norms and values moderate TCs and consequently affect entry decisions (Meyer, 2001b). Even decision-makers' personal emotions, which are influenced by informal institutions, have been shown to influence foreign investments (Van de Laar and De Neubourg, 2005).

The role of institutions is particularly important in acquisitions. In CEE, the institutions surrounding privatisation set the context for foreign acquisitions, which have a direct bearing on postacquisition strategies (Meyer, 2002) and performance (Uhlenbruck and De Castro, 2000). Other aspects of entry strategies, such as timing and location, may also be subject to formal and informal institutional constraints. For instance, industry-specific regulations and conditions for tenders to exploit natural resources influence investors' strategies and the acceleration of their commitment (McCarthy and Puffer, 1997). 
Most research in this area has focused on the impact of formal institutions on entry strategies, and the recognition of informal institutions (North, 1990) is relatively recent. Peng (2003) hypothesises that during the early phase of transition, when formal market-supporting institutions are less well developed and informal constraints dominate, foreign entrants are more likely to use JVs and alliances as opposed to wholly owned subsidiaries to enter CEE. This is supported by Meyer (2001b), who finds that foreign investors are more likely to use wholly owned ventures in the CEE countries with more advanced institutional development.

Institutional differences moreover affect operations spanning cultural boundaries because they face differences in informal institutions within their organisation (Child and Markóczy, 1993; Michailova, 2002). For instance, established business practices in the West may not have the same effect if applied in MNE affiliates in postsocialist societies. Thus, Fey and Björkman (2001) report that, in Western affiliates in Russia, teamwork combined with group-based reward systems has a positive effect when applied to nonmanagerial employees, but not for managers. This may be due to the traditionally hierarchical structure of CEE management and its discouragement of taking risk and responsibility.

Overall, the adaptation of strategies, structures and processes to institutional idiosyncrasies has been recognised as a major challenge for managers. IB and management research has so far taken only first steps to explore these linkages, and to provide advice on how MNE can manage these challenges.

\section{Incumbents' restructuring strategies}

ITs have been applied to analyse various aspects of local firms' restructuring. First, scholars aim to understand the antecedents in terms of the business cultures within CEE organisations. Second, scholars have investigated the phenomenon of widespread use of network-based interaction between agents and firms, and have used this observation as a starting point to develop an institution-based view of business strategy (Peng and Heath, 1996).

The first stream of research has applied ITs to study local incumbents or individuals. Many studies take an 'East $v s$ West' perspective, focusing on differences of national cultures as a result of institutional differences (Welsh et al., 1993; Pearce et al., 2000). A common starting point is the argument that socialism has created a distinct 'bloc culture'. For example, Frese et al. (1996) find that workers in eastern Germany show less initiative at work than their western German counterparts, and that patterns of individual behaviour in eastern Germany are more similar to those in neighbouring countries in CEE than to those in western Germany. Similarly, Makhija and Stewart (2002) document a lower level of willingness to take risk among Czech managers, relative to US peers.

The 'bloc culture' has been explored in several studies describing distinct institutional characteristics in transition economies. For example, Pearce et al. (2000) argue that, because of the communist 'neotraditionalist' political system, CEE organisations are highly particularist rather than universalist: that is, employees are rewarded based on who they are and what relationship they have with the persons in power, rather than on some universal, merit-based general rules. The influence of such institutional factors, however, competes with that of personal and professional characteristics. ${ }^{5}$

Cultures, and thus informal institutions, are often presumed to be constant, but CEE research has demonstrated that this is not the case. Many studies cited above relate cultural differences to different past and present institutional frameworks. This implies that they might fade away as CEE institutions converge with those in Western Europe. The region is going through a major cultural upheaval, as many individuals were abruptly confronted with Western culture represented by marketing, media and consultants - a phenomenon called 'collective culture shock' (Feichtinger and Fink, 1998). Thus, cultures change over time. For instance, younger Russians (under 30 years of age) have value systems that are radically different from those of the older generation (Ardichvili and Gasparishvili, 2003). However, some scholars observe fundamental cultural differences based on national, rather than bloc, culture, which are likely to be more persistent (Vlachoutsicos, 2000; Buck, 2003). CEE research has begun to analyse the dynamic and mutual interaction between businesses and changing institutional environments. This research may further explore the persistent and transient aspects of culture, as well as the determinants of cultural change. ${ }^{6}$

The second major line of IT research has analysed how differences in informal institutions shape the ways local incumbents conduct their business. A key insight is the identification of network-based strategies during the transition. Many CEE coun- 
tries' culture historically favours relying on personal relationships (e.g., blat in Russia) to get things done (Ledeneva, 1998). The shortage economy during the communist era has institutionalised some of the informal networking practices. Therefore, it is not surprising that CEE managers tend to resort to personal connections to achieve organisational goals during the transition.

Peng and Heath (1996) argue that the prevalence of network-based strategies is a reaction to the institutional frameworks in transition economies. The institutional conditions influence the relative merits of the three firm growth strategies featured in the literature:

(1) Generic expansion calls for an internal supply of resources such as capital, technology, and managers.

(2) Mergers and acquisitions (M\&As) require functioning strategic factor markets.

(3) Developing networks and alliances needs to build trust and mutual understanding.

Whereas the institutional frameworks supporting the first two strategies are formal ones, those for the last strategy are largely of an informal nature (Peng, 2000, 2003).

In CEE, generic expansion, based on firms' own resources, has typically been infeasible, at least initially, because many firms had to downsize. Second, handicapped by a lack of functioning formal capital markets, M\&As were not realistic either. In consequence, informal, network-based growth strategies were favoured by a variety of firms (Peng and Heath, 1996). These strategies emphasise intangible assets embodied in managers' micro, interpersonal ties and firms' macro, interorganisational relationships with various domestic and foreign partners - in short, a micro-macro link. Throughout CEE, the emergence of such a micromacro link has been reported in the Czech Republic (Spicer et al., 2000), Hungary (Stark, 1996), Russia (Ledeneva, 1998; Batjargal, 2003; Michailova and Worm, 2003), and Ukraine (Bridgewater, 1999).

The nature of relationships and the intensity of networking evolve with institutional change such that future strategies may be less reliant on personal networks (Peng, 2003). However, the way institutional changes translate into behavioural changes at the individual and firm levels remains a major research agenda. In particular, networks themselves may become institutionalised and a source of inertia, such that changes in formal institutions may only after considerable time lags lead to more arm's length transactions.

\section{Entrepreneurs' entry and growth strategies}

IT research has identified crucial barriers to the establishment, survival and growth of entrepreneurial firms (Estrin et al., 2005). A major World Bank project has identified the costs and time associated with establishing a new firm (Djankov et al., 2002). By many of these indicators, CEE is approaching West European levels, but with crucial exceptions. For example, in Romania, it takes 97 days and $54 \%$ of per capita GDP to set up a new business; in Russia, 57 days and 43\%; and in Hungary, 39 days and 101\%. In contrast, in the United States, it only takes 4 days and $1.7 \%$ of per capita GDP to start up a new venture; in Denmark, 3 days and 11\% (Djankov et al., 2002, 18-20).

Even after overcoming these barriers to entry, entrepreneurs have to operate without effective formal market-supporting institutions. Some authors emphasise the lack of credit for small firms (Pissarides et al., 2003; Kriauciunas, 2006), whereas others see the main obstacles in a wide range of informal institutions (Johnson et al., 2000; McMillan and Woodruff, 2002; Aidis and Mickiewicz, 2004), such as 'tax and regulatory burden, combined with the plunder by the numerous tax and regulatory authorities', and 'incumbents' use of authorities and/or racketeers to erect barriers against new entrants' (Kontorovich, 1999).

Like privatised incumbent firms, many newly established firms seek informal institutional support, such as personal networks, informal credit, and bartering, to substitute for formal institutions such as courts (McMillan and Woodruff, 2002, 162). As a result, entrepreneurial networking in transition economies has been noted for its intensity (Peng, 2001a). As smaller firms are disproportionately affected by market imperfections, they often have to intensify their networking activities with larger, more legitimate, and more powerful players (Peng, 2001a; McMillan and Woodruff, 2002). Theoretically, one would expect that the intensity of such networking would decrease as start-ups focus on more market capability-based strategies when market-supporting institutional transitions deepen (Peng, 2003). Yet, we still lack clear empirical evidence on which institutions affect the pattern of networking, and how institutional change would change the intensity of networking. 
Table 4 CEE issues associated with institutional theories

\begin{tabular}{|c|c|c|}
\hline Challenge to theory & Implications & Methodological challenges \\
\hline $\begin{array}{l}\text { Institutions, especially informal ones, are } \\
\text { highly idiosyncratic, and may vary along } \\
\text { dimensions not previously analysed }\end{array}$ & $\begin{array}{l}\text { Businesses need to adapt to each } \\
\text { institutional context, for example, } \\
\text { for effective HR strategies }\end{array}$ & $\begin{array}{l}\text { Need for good constructs and measures } \\
\text { to capture countries' informal institutions } \\
\text { (in addition to formal institutions) }\end{array}$ \\
\hline $\begin{array}{l}\text { Institutions are in constant change, } \\
\text { creating a highly volatile environment } \\
\text { and uncertainty about future institutional } \\
\text { arrangement }\end{array}$ & $\begin{array}{l}\text { Organisational forms of both local and } \\
\text { foreign businesses have to be designed } \\
\text { for flexibility, and be frequently } \\
\text { readjusted }\end{array}$ & $\begin{array}{l}\text { Need to identify and measure the } \\
\text { changes and impact of both formal and } \\
\text { informal institutions over time. Need to } \\
\text { study the impact of institutional } \\
\text { uncertainty and volatility on business }\end{array}$ \\
\hline $\begin{array}{l}\text { Cultural change under foreign influence, } \\
\text { and emergence of subcultures }\end{array}$ & $\begin{array}{l}\text { Contrary to what is often assumed, } \\
\text { culture may not be a constant }\end{array}$ & $\begin{array}{l}\text { Need to regularly update assessment } \\
\text { of culture, and to study the change } \\
\text { processes as such }\end{array}$ \\
\hline $\begin{array}{l}\text { Rapid institutional change interacts with } \\
\text { organisational change }\end{array}$ & $\begin{array}{l}\text { Rapid coevolutionary change between } \\
\text { institutions and organisations }\end{array}$ & $\begin{array}{l}\text { Need to observe, record, and model the } \\
\text { interdependent change processes }\end{array}$ \\
\hline
\end{tabular}

Evaluation of theory application and development ITs thrive because of their simplicity in logic and complexity in operationalisation (McKinley et al., 1999). Few will dispute the simple proposition that 'institutions matter', but how they matter remains a subject not only of intense scholarly interest but also of significant public policy debate. In the privatisation literature, an influential school of thought argues that, upon privatising SOEs, effective restructuring would presumably follow (Boycko et al., 1995, 150). However, in the absence of market-supporting institutions, the 'triumphant completion' of privatisation in countries such as Russia (Boycko et al., 1995, 8) may end up being a 'premature verdict' (Williamson, 2000, 610). IB and management research on CEE has reinforced and enriched ITs, by arguing that 'markets are always embedded in institutions. There is no atomistic market of textbook theory, because such markets cannot be observed in practice' (Kogut and Spicer, 2002, 9, added italics). On the other hand, despite rapid progress, leading institutional theorists confess that 'we are still very ignorant about institutions' (Williamson, 2000, 595).

The existing non-CEE institutional literature tends to flow from a set of known institutional 'rules of the game' and then to explore certain organisational responses (North, 1990; Ingram and Silverman, 2002). As a result, the literature does not provide a ready set of answers to new questions emerging in CEE (Table 4). For instance, 'How do organizations play the new game when the new rules are not completely known?' (Peng, 2003, 283), and how does rapid institutional change co-evolve with organizational change? CEE research has moved the frontier of IT research by providing some initial answers (or experiments) as to how these relevant, interesting, but largely untackled questions can be entertained. These efforts thus lead to the emergence of an institution-based view of business strategy, which complements the existing industry- and resource-based views (Peng, 2006). For instance, the refutation of the 'Lego' model of the firm (discussed earlier) speaks directly to the importance of the ITs.

\section{Conclusion: a future research agenda}

The 'natural experiments' in transition economies continue to generate unique research needs and opportunities. Table 5 outlines a number of puzzles and questions for future research. First, TCT and AT research face a context where some of their standard assumptions do not apply. This requires finer-grained modelling of incentives and agency relationships, incorporating formal as well as informal lines of power of various stakeholders in the specific context.

Future RBT research may explore which resources are most crucial in such environments, and how context-specific resources are developed by interaction of global and local processes. A second line of research may analyse the adaptation of resources transferred from mature market economies to transition economies and the absorptive capacity facilitating such transfer and adaptation. At a more general level, the creation, transfer and exploitation of resources during radical change merits analysis grounded in an evolutionary perspective.

Scholars analysing the impact of institutions on individual and firm behaviour may want to develop 
Table 5 Some puzzles and future questions

\begin{tabular}{|c|c|c|c|}
\hline Theories & Foreign investors' entry strategies & $\begin{array}{l}\text { Local incumbents' restructuring } \\
\text { strategies }\end{array}$ & $\begin{array}{l}\text { Entrepreneurs' entry and growth } \\
\text { strategies }\end{array}$ \\
\hline $\begin{array}{l}\text { Organisational } \\
\text { economics theories }\end{array}$ & $\begin{array}{l}\text { How do variations of transaction } \\
\text { costs between countries and } \\
\text { over time explain variations of } \\
\text { entry modes (Brouthers and } \\
\text { Brouthers, 2003)? }\end{array}$ & $\begin{array}{l}\text { Why are outside board directors } \\
\text { and new managers, } \\
\text { hypothesised by standard AT } \\
\text { models, unable to make a } \\
\text { difference in firm performance } \\
\text { (Peng et al., 2003)? }\end{array}$ & $\begin{array}{l}\text { What are the appropriate } \\
\text { governance structures for local } \\
\text { start-ups? }\end{array}$ \\
\hline Resource-based theories & $\begin{array}{l}\text { Why is perceived organisational } \\
\text { fit between foreign and } \\
\text { domestic firms, long regarded } \\
\text { as a crucial resource for } \\
\text { acquisition success, negatively } \\
\text { correlated with postacquisition } \\
\text { performance (Uhlenbruck and } \\
\text { De Castro, 2000)? }\end{array}$ & $\begin{array}{l}\text { How do firms manage the } \\
\text { reconfiguration of their } \\
\text { resources necessitated by a } \\
\text { changing environment } \\
\text { (Uhlenbruck et al., 2003; } \\
\text { Newman, 2000)? }\end{array}$ & $\begin{array}{l}\text { Why do some start-ups that } \\
\text { aggressively internationalise, } \\
\text { often regarded as a crucial } \\
\text { capability to help them } \\
\text { succeed, have a lower likelihood } \\
\text { of survival (Lyles et al., 2004)? }\end{array}$ \\
\hline
\end{tabular}

this research towards a comprehensive theory. This would require finer-grained explanations of how formal and informal institutions matter. At least two areas await further development. First, thus far, much institutional analysis has focused primarily on the comparison between CEE and the West, the latter often being represented by the United States. Although useful to a certain extent, such comparison fails to explore institutional similarities and differences in other settings. Using, for example, Italy or France as a benchmark, it would be less surprising to find an institutional environment in which personal networks are important and where SOEs contribute a major share in the economy. In addition, variations across transition and emerging economies (e.g., CEE vs China) remain poorly understood. So far only few studies directly compare business in China and a CEE economy (Child and Markóczy, 1993; Buck et al., 2000; White and Linden, 2002; Michailova and Worm, 2003; Hitt et al., 2004).

Another research direction is to sort out the 'boiling cauldron of ideas' within the broad 'church' called new institutionalism (Williamson, 2000, 610). At present, IB and management research has identified a number of institutionally derived forces, such as TCs (Meyer, 2001b), political risks (Henisz, 2000), and relational networks (Peng and Heath, 1996). Although these mechanisms are, to a large degree, complementary, future research needs to integrate them in more comprehensive theorising.

While being the first in the literature to comprehensively review theoretically driven CEE research in IB and management, this article is not without its limitations. First, it fails to cover nonmanagement research. ${ }^{7}$ Second, similar to Werner (2002, 278), our identification of the three sets of leading theories is based on our own readings of (and contributions to) the literature. This admittedly reflects some of our own biases. Finally, we have focused on only one region, CEE. However, similar phenomena also arise in research on other emerging economies (Wright et al., 2005). For example, Khanna and Rivkin's (2001) work on diversification strategies in emerging economies clearly points to the impact of institutional factors on business strategies. Estrin and Meyer (2004) report that the brownfield phenomenon first identified in CEE (Meyer and Estrin, 2001) is also found as far away as Egypt and India.

Overall, we anticipate that future research will integrate currently separate research efforts in different regions with more comparative studies, 
including CEE and other regions such as Asia, Latin America, and Africa. Moreover, we expect that some of the issues analysed in CEE are of interest to other regions. For instance, CEE has been at the forefront of privatisation. Thus, issues of postprivatisation governance as well as integration of acquired former SOEs are likely to emerge in other regions as well. More broadly, we believe that the institution-based view of business strategy is likely to contribute to the global strategy research agenda. In conclusion, we hope that our discussion of the pertinent theories will stimulate future research not only in CEE but also well beyond CEE.

\section{Acknowledgements}

Meyer thanks support from the Centre for East European Studies at Copenhagen Business School and the Danish Social Science Foundation (Project No. 24-01-0152). Peng acknowledges funding from the Ohio State University's Centre for Slavic and East European Studies and Center for International Business Education and Research as well as the National Science Foundation (CAREER Grant SES 0238820, formerly known as a Young Investigator Award). Earlier versions were presented at the Academy of International Business meeting in Puerto Rico (2002), Henley Management College (2004), and the University of Nottingham (2004). We thank conference and seminar participants, JIBS reviewers, Arnold Schuh, Brian Silverman (editor), Klaus Uhlenbruck, and Mike Wright for helpful comments and discussions, and Jana Penzes, Yen Thi Thu Tran, Yuanyuan Zhou, and David Zhu for excellent research assistance. All views expressed are ours and not necessarily those of the funding organisations.

\footnotetext{
Notes

${ }^{1}$ For the purposes of this article, Central and Eastern Europe (CEE) includes the former Soviet Union as well as Central Europe.

${ }^{2}$ These three lines of theorising arguably correspond to the three pillars of the dominant paradigm in IB research, the OLI paradigm developed by Dunning (1993). RBTs explore ownership advantages (O); ITs analyse an important aspect of locational advantages (L); and TCT underpins internalisation incentives (I). However, it is important to note that the OLI paradigm has been developed to explain the rationale for international production (and hence the existence of multinational enterprises), whereas the three sets of
}

leading theories we identify deal with a wider range of topics beyond the traditional coverage of the OLI paradigm.

${ }^{3}$ In IB research, TCT has been applied as internalisation theory as one of the three 'pillars' of the 'eclectic paradigm' to explain why MNEs choose different governance arrangements when operating abroad (Dunning, 1993). CEE research has pushed the frontier of this paradigm further by demonstrating that it cannot only be used to predict entry modes, but can also be linked with performance (Brouthers et al., 1999; Nakos and Brouthers, 2002). In other words, this research documents that firms that use variables specified in the eclectic paradigm when selecting entry modes are more satisfied with their CEE performance than those that do not, thus suggesting that Dunning's eclectic paradigm is 'normative as well as descriptive' (Brouthers et al., 1999: 841).

${ }^{4}$ Within the broad institutional literature, there are substantial debates, such as those between institutional economists and sociologists. However, in the relatively disciplinary 'neutral' fields of IB and management research, scholars have generally avoided participating in these discipline-based debates, and have taken the liberty to take the best available insights that can best inform the research questions at hand (see Peng and Heath, 1996; Peng, 2003). This integrative approach is also recommended by Scott (1995). In this article, we choose to follow this approach and do not engage in the debates within various institutional subfields. Specifically, we refer here to 'institutions' in the external environment of the firm as analysed in economics (North, 1990) and sociology (Scott, 1995). This concept of 'institutions' incorporates the frequently used concept of culture, which is 'a substratum of institutional arrangements' (Hofstede et al., 2002: 800). Therefore, we interpret studies dealing with cultural differences to be within the broader institutional literature focusing on the informal aspects of institutional constraints.

${ }^{5}$ For instance, Markóczy (2000) finds that common beliefs among individuals in Hungarian firms are more strongly associated with membership in the same functional area than with nationality.

${ }^{6} \mathrm{~A}$ particularly fruitful opportunity for research on cultural change arises with the expansion of the EU, which now incorporates most Central European and Baltic countries. Given that individuals and firms in EU member countries are presumably more homogeneous than those in nonmember countries, it will be interesting to hypothesise the convergence of 
individual beliefs and business strategies between Central and Western European EU member countries and the divergence between them and the former Soviet Union countries (except the Baltics, which have joined the EU).

${ }^{7}$ Although we acknowledge that the lack of coverage of nonmanagement research on CEE is a limita- tion, it is important to note that management is the largest contributing discipline to IB research in general and to JIBS in particular (Peng, 2001b: 822). In addition, relative to management, other business disciplines such as accounting, finance, marketing and MIS have less coverage on IB (Werner and Brouthers, 2002: Tables 1 and 2) and much less on CEE.

\section{References}

Aidis, R. and Mickiewicz, T. (2004) 'Which entrepreneurs expect to expand their business? Evidence from survey data in Lithuania', William Davidson Institute Working Paper Number 723, October.

Allmendinger, J. and Hackman, J.R. (1996) 'Organizations in changing environments: the case of East German symphony orchestras', Administrative Science Quarterly 41: 337-369.

Anderson, E. and Gatignon, H. (1986) 'Modes of foreign entry: a transaction cost analysis and propositions', Journal of International Business Studies 17: 1-26.

Antal-Mokos, Z. (1998) Privatisation, Politics, and Economic Performance in Hungary, Cambridge University Press: Cambridge.

Ardichvili, A. and Gasparishvili, A. (2003) 'Russian and Georgian entrepreneurs and non-entrepreneurs: a study of value differences', Organization Studies 24: 29-46.

Barney, J. (1991) 'Firm resources and sustainable competitive advantage', Journal of Management 17: 99-120.

Batjargal, B. (2003) 'Social capital and entrepreneurial performance in Russia: a longitudinal study', Organization Studies 24: 535-556.

Belev, B. (2003) 'Institutional investors in Bulgarian corporate governance reform: obstacles or facilitators?' Journal of World Business 38: 361-374.

Benito, G.R.G., Pedersen, T. and Petersen, B. (1999) 'Foreign operation modes and switching costs: conceptual issues and possible effects', Scandinavian Journal of Management 15: 213-239.

Bevan, A., Estrin, S. and Meyer, K.E. (2004) 'Foreign investment location and institutional development in transition economies', International Business Review 13: 43-64.

Blaszejewski, S. and Dorow, W. (2003) 'Managing organizational politics for radical change in the case of Beiersdorf-Lechia S.A., Poznan', Journal of World Business 38(3): 65-167.

Boerner, C. and Macher, J. (2004) 'Transaction cost economics: an assessment of empirical research in the social sciences' Working Paper, Haas School of Business, University of California, Berkeley.

Boycko, M., Shleifer, A. and Vishny, R. (1995) Privatizing Russia, MIT Press: Cambridge, MA

Bridgewater, S. (1999) 'Networks and internationalisation: the case of multinational corporations entering Ukraine', International Business Review 8: 99-118.

Brouthers, K.D. and Bamossy, G. (1997) 'The role of key stakeholders in international joint venture negotiations: case studies from Eastern Europe', Journal of International Business Studies 28: 285-308.

Brouthers, K.D. and Brouthers, L.E. (2001) 'Explaining the national cultural distance paradox', Journal of International Business Studies 32: 177-189.

Brouthers, K.D. and Brouthers, L.E. (2003) 'Why service and manufacturing entry mode choices differ: the influence of transaction cost factors, risk and trust', Journal of Management Studies 40(5): 1179-1204.

Brouthers, L.E., Brouthers, K.D. and Werner, S. (1999) 'Is Dunning's eclectic framework descriptive or normative?' Journal of International Business Studies 30: 831-844.

Buck, T. (2003) 'Modern Russian corporate governance: convergent forces or product of Russia's history?' Journal of World Business 38(4): 299-313.

Buck, T., Filatotchev, I., Nolan, P. and Wright, M. (2000) 'Different paths to economic reform in Russia and China: causes and consequences', Journal of World Business 35: 379-394.

Buck, T., Filatotchev, I. and Wright, M. (1998) 'Agents, stakeholders, and corporate governance in Russian firms', Journal of Management Studies 35: 81-104.

Carroll, G., Godstein, J. and Gyenes, A. (1988) 'Organizations and the state: effects of the institutional environment on cooperatives in Hungary', Administrative Science Quarterly 33: 233-256.

Child, J. and Czegledy, A.P. (1996) 'Managerial learning in the transformation of Eastern Europe: some key issues', Organization Studies 17: 167-180.

Child, J. and Markóczy, L. (1993) 'Host-country managerial behavior and learning in Chinese and Hungarian joint ventures', Journal of Management Studies 30: 611-631.

Clark, E. and Soulsby, A. (1995) 'Transforming former state enterprises in the Czech Republic', Organization Studies 16: 215-242.

Csaban, L. Hocevar, M Jaklic, M and Whitley, R. (2003)' Path dependence and contractual relations in emergent capitalism: contrasting state socialist legacies and inter-firm cooperation in Hungary and Slovenia', Organization Studies 14: 7-28.

Dhanaraj, C. Lyles, M.A., Steensma, H.K. and Tihanyi, L. (2004) 'Managing tacit and explicit knowledge transfer in IJVs: the role of relational embeddedness and the impact on performance', Journal of International Business Studies 35: 428-442.

Djankov, S. and Murrell, P. (2002) 'Enterprise restructuring in transition: a quantitative survey', Journal of Economic Literature 40: 739-792.

Djankov, S., La Porta, R., Lopez-de-Silanes, F. and Shleifer, A. (2002) 'The regulation of entry', Quarterly Journal of Economics 117: 1-37.

Dobrev, S. (2000) 'Decreasing concentration and reversibility of the resource partitioning process: supply and deregulation in the Bulgarian newspaper industry', Organization Studies 21: 383-404.

Dunning, J. (1993) Multinational Enterprises and the Global Economy, Addison-Wesley: Wokingham, UK.

Elenkov, D. (1998) 'Can American management concepts work in Russia? A cross-cultural comparative study', California Management Review 40: 133-156.

Elenkov, D.S. (2002) 'Effects of leadership on organizational performance in Russian companies', Journal of Business Research 55: 467-480.

Estrin, S. (2002) 'Competition and corporate governance in transition', Journal of Economic Perspectives 16: 101-124.

Estrin, S., Hughes, K. and Todd, S. (1997) Foreign Direct Investment in Central and Eastern Europe: Multinationals in Transition, Pinter: London.

Estrin, S. and Meyer, K.E. (eds.) (2004) Investment Strategies in Emerging Markets, Elgar: Cheltenham. 
Estrin, S., Meyer, K.E. and Bytchkova, M. (2005) 'Entrepreneurship in transition economies', in M.C. Casson et al. (eds.) Oxford Handbook of Entrepreneurship, Oxford University Press Oxford, (forthcoming).

Fahy, J., Hooley, G., Cox, T., Beracs, J., Fonfoara, K. and Snoj, B. (2000) 'The development and impact of marketing capabilities in Central Europe', Journal of International Business Studies 31: $63-82$.

Feichtinger, C. and Fink, G. (1998) 'The collective culture shock in transition countries', Leadership and Organizational Development Journal 19: 302-324.

Fey, C.F. and Beamish, P.W. (2001) 'The importance of organizational climate similarity between parent firms and the JV: the case of IJVs in Russia', Organization Studie 22: 853-882.

Fey, C.F. and Björkman, I. (2001) 'The effect of human resource management practices on MNC subsidiary performance in Russia', Journal of International Business Studies 32: 59-75.

Fey, C.F., Bjorkman, I. and Pavlovskaya, A. (2000) 'The effect of human resource management practices on firm performance in Russia', International Journal of Human Resource Management 11: 1-18.

Fey, C.F., Adaeva, M. and Vitkovskaia, A. (2001) 'Developing a model of leadership styles: what works best in Russia?' International Business Review 10: 615-643.

Filatotchev, I., Buck, T. and Zhukov, V. (2000) 'Downsizing privatized firms in Russia, Ukraine, and Belarus', Academy of Management Journal 43: 286-304.

Filatotchev, I., Dyomina, N., Wright, M. and Buck, T. (2001) 'Effects of post-privatization governance and strategies on export intensity in the former Soviet Union', Journal of International Business Studies 32: 853-871.

Filatotchev, I., Hoskisson, R.E., Buck, T. and Wright, M. (1996) 'Corporate restructuring in Russian privatizations: implications for US investors', California Management Review 38: 87-105

Filatotchev, I., Wright, M., Uhlenbruck, K., Tihanyi, L. and Hoskisson, R.E. (2003) 'Governance, organizational capabilities, and restructuring in transition economies', Journal of World Business 38(4): 331-347.

Fiol, C.M. and Lyles, M.A. (1985) 'Organizational learning', Academy of Management Review 10(4): 803-813.

Frese, M., Kring, W., Soose, A. and Zempel, J. (1996) 'Personal initiative at work: differences between East and West Germany', Academy of Management Journal 39: 37-63.

Henisz, W. (2000) 'The institutional environment for multinational investment', Journal of Law, Economics, and Organiza tion 16: 334-364.

Hennart, J.F. (1988) 'A transaction costs theory of equity joint ventures', Strategic Management Journal 9: 361-374.

Hitt, M.A., Ahlstrom, D., Dacin, M.T., Levitas, E. and Svobodina, L. (2004) 'The institutional effects on strategic alliance partne' selection in transition economies: China versus Russia', Organization Science 15: 173-185.

Hitt, M.A., Dacin, T., Levitas, E., Arregle, J. and Borza, A. (2000) 'Partner selection in emerging market contexts: resourcebased and organizational learning perspectives', Academy of Management Journal 43: 449-467.

Hofstede, G., Deusen, V.C., Mueller, C., Charles, T., and Business Goals Network (2002) 'What goals do business leaders pursue?' Journal of International Business Studies 33: 785-803.

Holt, D.H., Ralston, D.A. and Terpstra, R.H. (1994) 'Constraints on capitalism in Russia: the managerial psyche, socia infrastructure, and ideology', California Management Review 36: 124-142.

Hoskisson, R., Eden, L., Lau, C. and Wright, M. (2000) 'Strategy in emerging economies', Academy of Management Journal 43 249-267.

Ingram, P. and Silverman, B. (2002) 'Introduction', in P. Ingram and B. Silverman (eds.) The New Institutionalism in Strategic Management, Elsevier: Amsterdam, pp. 1-30.
Javorcik, B.S. (2004) 'The composition of foreign direct investment and protection of intellectual property rights: evidence from transition economies', European Economic Review 48: 39-62.

Jensen, M. and Meckling, W. (1976) 'Theory of the firm: managerial behavior, agency costs, and ownership structure', Journal of Financial Economics 3: 305-360.

Johnson, S. and Loveman, G.W. (1996) Starting Over in Eastern Europe: Entrepreneurship and Economic Revival, Harvard Business School Press: Cambridge, MA.

Johnson, S., McMillan, J. and Woodruff, C. (2000) 'Entrepreneurs and the ordering of institutional reform', Economics of Transition 8(1): 1-36.

Jones, D. and Mygind, N. (1999) 'The nature and determinants of ownership changes after privatization: evidence from Estonia', Journal of Comparative Economics 27: 422-441.

Khanna, T. and Rivkin, J.W. (2001) 'Estimating the performance effects of business groups in emerging markets', Strategic Management Journal 22: 45-74.

Kogut, B. and Spicer, A. (2002) 'Capital market development and mass privatization are logical contradictions: lessons from Russia and the Czech Republic', Industrial and Corporate Change 11: 1-37.

Kogut, B. and Zander, U. (1993) 'Knowledge of the firm and the evolutionary theory of the multinational corporation', Journal of International Business Studies 24: 625-645.

Kogut, B. and Zander, U. (2000) 'Did socialism fail to innovate? A natural experiment of the two Zeiss companies', American Sociological Review 65: 165-190.

Kontorovich, V. (1999) 'Has new business creation in Russia come to a halt?' Journal of Business Venturing 14: 451-460.

Kriauciunas, A.P. (2006) 'Sunflower Company: Adapting to changing market conditions', in M.W. Peng (ed.) Global Strategy, Thomson South-Western: Cincinnati, pp: 171-176.

Lane, P.. Salk, J. and Lyles, M. (2001) 'Absorptive capacity, learning, and performance in international joint ventures', Strategic Management Journal 22: 1139-1161.

Ledeneva, A. (1998) Russia's Economy of Favours: Blat, Networking, and Informal Exchange, Cambridge University Press: Cambridge.

Lu , J.W. (2003) 'The evolving contributions in international strategic management research', Journal of International Management 9: 193-213.

Luthans, F., Welsh, D.H.B. and Rosenkrantz, S.A. (1993) 'What do Russian managers really do? An observational study with comparisons to US managers', Journal of International Business Studies 24: 741-761.

Lyles, M.A. and Baird, I.S. (1994) 'Performance of international joint-ventures in two Eastern European countries: the Case of Hungary and Poland', Management International Review 34: 313-329.

Lyles, M. and Salk, J. (1996) 'Knowledge acquisition from foreign parents in international joint ventures: an empirical examination in the Hungarian context', Journal of International Business Studies 27: 877-903.

Lyles, M., Saxton, T. and Watson, K. (2004) 'Venture survival in a transition economy', Journal of Management 30(3): 351-375.

Makhija, M. (2003) 'Comparing the resource-based and market-based views of the firm: empirical evidence from Czech privatization', Strategic Management Journal 24(5): 433-452.

Makhija, M. (2004) 'The value of restructuring in emerging economies: the case of the Czech Republic', Strategic Management Journal 25: 243-267.

Makhija, M. and Stewart, A. (2002) 'The effect of national context on perceptions of risk: a comparison of planned versus free-market managers', Journal of International Business Studies 33: 737-756.

Markóczy, L. (1997) 'Measuring beliefs: accept no substitutes', Academy of Management Journal 40: 1228-1242. 
Markóczy, L. (2000) 'National culture and strategic change in belief formation', Journal of International Business Studies 31 : 427-442.

May, C.R., Steward Jr., W.H. and Sweo, R. (2000) 'Environmental scanning behavior in a transitional economy: evidence from Russia', Academy of Management Journal 43: 403-427.

McCarthy, D. and Puffer, S. (1997) 'Strategic investment flexibility for MNE success in Russia: evolving beyond entry modes', Journal of World Business 32: 293-319.

McCarthy, D. and Puffer, S. (2003) 'Corporate governance in Russia: a framework for analysis', Journal of World Business 38: 397-415.

McCarthy, D., Puffer, S. and Naumov, A. (1997) 'Partnering with Russia's new entrepreneurs: software tsarina Olga Kirova', European Management Journal 15: 648-657.

McKinley, W., Mone, M. and Moon, G. (1999) 'Determinants and development of schools in organization theory', Academy of Management Review 24: 634-648.

McMillan, J. and Woodruff, C. (2002) 'The central role of entrepreneurs in transition economies', Journal of Economic Perspectives 16: 153-170.

Megginson, W. and Netter, J. (2001) 'From state to market: a survey of empirical studies on privatization', Journal of Economic Literature 39: 321-389.

Meyer, K.E. (1998) Direct Investment in Economies in Transition, Elgar: Aldershot.

Meyer, K.E. (2001a) 'International business research on transition economies', in A. Rugman and T. Brewer (eds.) Oxford Handbook of International Business, Oxford University Press: Oxford, pp: 716-759.

Meyer, K.E. (2001b) 'Institutions, transaction costs, and entry mode choice in Eastern Europe', Journal of International Business Studies 32: 357-367.

Meyer, K.E. (2002) 'Management challenges in privatization acquisitions in transition economies', Journal of World Business 37: $266-276$

Meyer, K.E. (2004) 'Stakeholder influence and radical change: a coordination game perspective', Asia Pacific Journal of Management 21: 235-253.

Meyer, K.E. and Estrin, S. (2001) 'Brownfield entry in emerging markets', Journal of International Business Studies 32: 575-584.

Meyer, K.E. and Lieb-Dóczy, E. (2003) 'Post-acquisition restructuring as evolutionary process', Journal of Management Studies 40: 459-482.

Michailova, S. (2000) 'Contrasts in culture: Russian and Western perspectives on organizational change', Academy of Manage ment Executive 14(4): 99-112.

Michailova, S. (2002) 'When common sense becomes uncommon: participation and empowerment in Russian companies with Western participation', Journal of World Business 37 180-187.

Michailova, S. and Worm, V. (2003) 'Personal networking in Russia and China: Blat and guanxi', European Management Journal 23: 509-519.

Minbaeva, D., Pedersen, T., Björkman, I., Fey, C.F. and Park, H.J. (2003) 'MNC knowledge transfer, subsidiary absorptive capacity and $\mathrm{HRM}^{\prime}$, Journal of International Business Studies 24: 586-599.

Mueller, S. and Clarke, L. (1998) 'Political economic context and sensitivity to equity: differences between the United States and the transition economies of Central and Eastern Europe', Academy of Management Journal 41: 319-329.

Mygind, N. (2001) 'Enterprise governance in transition: a stakeholder perspective', Acta Oeconomica 51: 315-342.

Nakos, G. and Brouthers, K.D. (2002) 'Entry mode choice of SMEs in Central and Eastern Europe', Entrepreneurship Theory and Practice 27: 47-64.

Newman, K. (2000) 'Organizational transformation during institutional upheaval', Academy of Management Review 25: 602-619.
Nickerson, J.A and Silverman, B.S. (2003) 'Why firms want to organize efficiently and what keeps them from doing so: inappropriate governance, performance, and adaptation in a deregulated industry', Administrative Science Quarterly 48: 433-465.

North, D. (1990) Institutions, Institutional Change, and Economic Performance, Norton: New York.

Oxley, J.E. (1999) 'Institutional environment and the mechanisms of governance: the impact of intellectual property protection on the structure of inter-firm alliances', Journal of Economic Behavior and Organization 24: 283-310.

Pearce, J., Branyiczki, I. and Bigley, G. (2000) 'Insufficient bureaucracy: trust and commitment in particularistic organizations', Organizational Science 11: 148-162.

Peng, M.W. (2000) Business Strategies in Transition Economies, Sage: Thousand Oaks, CA.

Peng, M.W. (2001a) 'How entrepreneurs create wealth in transition economies', Academy of Management Executive 15(1): 95-108.

Peng, M.W. (2001b) 'The resource-based view and international business', Journal of Management 27(6): 803-829.

Peng, M.W. (2003) 'Institutional transitions and strategic choices', Academy of Management Review 28(2): 275-296.

Peng, M.W. (2006) Global Strategy, Thomson South-Western: Cincinnati, $\mathrm{OH}$.

Peng, M.W., Buck, T. and Filatotchev, I. (2003) 'Do outside directors and new managers help improve firm performance? An exploratory study in Russian privatization', Journal of World Business 38(4): 348-360.

Peng, M.W. and Heath, P. (1996) 'The growth of the firm in planned economies in transition: institutions, organizations, and strategic choices', Academy of Management Review 21(2): 492-528.

Pissarides, F., Singer, M. and Svejnar, J. (2003) 'Objectives and constraints of entrepreneurs: evidence from small and medium size firms in Russia and Bulgaria', Journal of Comparative Economics 31: 503-531.

Puffer, S. (1994) 'Understanding the bear: a portrait of Russian business leaders', Academy of Management Executive 8(1): 41-54.

Puffer, S. and McCarthy, D. (1995) 'Finding the common ground in Russian and American business ethics', California Management Review 37: 29-47.

Puffer, S. and McCarthy, D. (2001) 'Navigating the hostile maze: a framework for Russian entrepreneurship', Academy of Management Executive 15(4): 24-36.

Ralston, D., Holt, D., Terpstra, R. and Yu, K. (1997) 'The impact of national culture and economic ideology on managerial work values: a study of the United States, Russia, Japan, and China', Journal of International Business Studies 28: 177-207.

Ramamurti, R. (1992) 'Why are developing countries privatizing?', Journal of International Business Studies 23: 225-249.

Ramamurti, R. (2001) 'The obsolescing 'bargaining model'? MNC-host developing country relations revisited', Journal of International Business Studies 32: 23-439.

Reynolds, P.D., Bygrave, W.D, Autio, E. and Hay, M. (2002) 'Global entrepreneurship monitor: 2002 summary report', Babson College, Ewing Kaufman Foundation and London Business School.

Scott, W.R. (1995) Institutions and Organizations, (2nd edn: 2001) Sage: Thousand Oaks, CA

Sorge, A. and Brussig, M. (2003) 'Organizational process, strategic content and socio-economic resources: small enterprises in East Germany, 1990-94', Organization Studies 24: 1261-1281.

Spicer, A., McDermott, G. and Kogut, B. (2000) 'Entrepreneurship and privatization in Central Europe: the tenuous balance between destruction and creation', Academy of Management Review 25: 630-649. 
Stark, D. (1996) 'Recombinant property in East European capitalism', American Journal of Sociology 101: 993-1027.

Steensma, H.K. and Lyles, M. (2000) 'Explaining IJV survival in a transitional economy through social exchange and knowledge-based perspectives', Strategic Management Journal 21: $831-851$.

Suhomlinova, O.O. (1999) 'Constructive destruction: transformation of Russian state-owned construction enterprises during market transition', Organization Studies 20: 451-484.

Svejnar, J. (2002) 'Transition economies: performance and challenges', Journal of Economic Perspectives 16: 3-28.

Swaan, W. (1997) 'Knowledge, transaction costs and the creation of markets in post-socialist economies', in P.G. Hare and J. Davis (eds.) Transition to the Market Economy, Routledge: London, pp: 53-76.

Teece, D., Pisano, G. and Shuen, A. (1997) 'Dynamic capabilities and strategic management', Strategic Management Journal 18: 509-533.

Uhlenbruck, K. (2004) 'Developing acquired foreign subsidiaries: the experience of MNEs in transition economies', Journa of International Business Studies 35: 109-123.

Uhlenbruck, K. and De Castro, J. (1998) 'Privatization from the acquirer's perspective: a mergers and acquisitions based framework', Journal of Management Studies 35: 619-640.

Uhlenbruck, K. and De Castro, J. (2000) 'Foreign acquisitions in Central and Eastern Europe: outcomes of privatization in transition economies', Academy of Management Journal 43 381-402.

Uhlenbruck, K., Meyer, K.E. and Hitt, M. (2003) 'Organizational transformation in transition economies: resource-based and organizational learning perspectives', Journal of Management Studies 40: 257-282.

Van de Laar, M. and De Neubourg, C. (2005) 'Emotions and foreign direct investment: a theoretical and empirical exploration', Management International Review, forthcoming.

Vlachoutsicos, C. (2000) 'Russian communitarianism', in D. Denison (ed.) Managing Organizational Change in Transition Economies, LEA: Mahway, NJ.

Weber, E.U. and Hsee, C. (1998) 'Cross-cultural differences in risk perception, but cross-cultural similarities in attitudes towards perceived risk', Management Science 44: 1205-1217.

Welsh, D.H.B., Luthans, F. and Sommer, S.M. (1993) 'Managing Russian factory workers: the impact of US-based behavioral and participative techniques', Academy of Management Journal 36: 58-79.

Werner, S. (2002) 'Recent developments in international management research: a review of 20 top management journals', Journal of Management 28: 277-305.

Werner, S. and Brouthers, L.E. (2002) 'How international is management?' Journal of International Business Studies 33(3): 583-592.

White, S. and Linden, G. (2002) 'Organizational and industrial response to market liberalization: the interaction of pace, incentive and capacity to change', Organization Studies 23: 917-948.

Whitley, R. and Csaban, L. (1998) 'Institutional transformation and enterprise change in an emergent capitalist economy: the case of Hungary', Organization Studies 19: 129-180.

Whitley, R., Henderson, J., Lengyul, G. and Csaban, L. (1996) 'Trust and contractual relations in an emerging capitalist economy: the changing trading relationships of ten large Hungarian enterprises', Organization Studies 17: 397-420.

Williamson, O.E. (1991) 'Comparative economic organization: the analysis of discrete structural alternatives', Administrative Science Quarterly 36: 269-297.

Williamson, O.E. (2000) 'The new institutional economics: taking stock, looking ahead', Journal of Economic Literature 38: 595-613.

Wright, M. Filatotchev, I. Hoskisson, R.E. and Peng, M.W. (2005) 'Strategy research in emerging economies: challenging the conventional wisdom', Journal of Management Studies 42: $1-33$
Zahra, S., Ireland, R.D., Gutierrez, I. and Hitt, M. (2000) 'Privatization and entrepreneurial transformation', Academy of Management Review 25: 525-550.

\section{Appendix A: Mapping the contributions}

In preparation for this article, we have systematically collected all CEE-related articles in 13 leading IB and management journals published during 1986-2004 (inclusive). They include 137 articles published by eight North America-based journals: the Academy of Management Journal ( 9 articles), Academy of Management Review (4), Administrative Science Quarterly (2), Journal of Business Research (8), Journal of International Business Studies (26), Journal of International Management (5), Journal of World Business (72), Organization Science (4), and Strategic Management Journal (7). A total of 81 articles are published by four Western Europe-based journals: International Business Review (21), Journal of Management Studies (11), Management International Review (19), and Organization Studies (30). A full list of these 218 articles can be found in the literature review section of the JIBS website (http://copenhagen.jibs.net/LitReviewsInfo.asp).

Table A1 reports some summary data on this diverse research. In columns 1 and 2 we report the leading individual and institutional contributors ranked in terms of the weighted numbers of publications in these top journals. Russia expert Sheila Puffer and her institution, Northeastern University, emerge as the most prolific contributors. Columns 3 and 4 list the most frequently cited papers in the SSCI database as of 31 December 2004. The most cited works include papers that cover both CEE and Asia, be it theoretical papers such as Peng and Heath (1996), empirical studies such as Child and Markóczy (1993), Ralston et al. (1997), and Hitt et al. (2000), or the introduction to a special issue by Hoskisson et al. (2000). The most cited papers analysing business in a specific CEE country are Frese et al. (1996) on worker motivation in East and West Germany [column 3] and Newman (2000) on enterprises in the Czech Republic [column 4].

Tabulating citations in this form is not without methodological problems. First, because we only systematically cover IB and management journals, we do not pay systematic attention to influential research in economics (e.g., Estrin, 2002; McMillan and Woodruff, 2002) and sociology (e.g., Stark, 1996; Ledeneva, 1998). Second, some influential research has been published as books, such as Peng 
许 Probing theoretically into Central and Eastern Europe Klaus E Meyer and Mike W Peng

Table A1 Contributor analysis

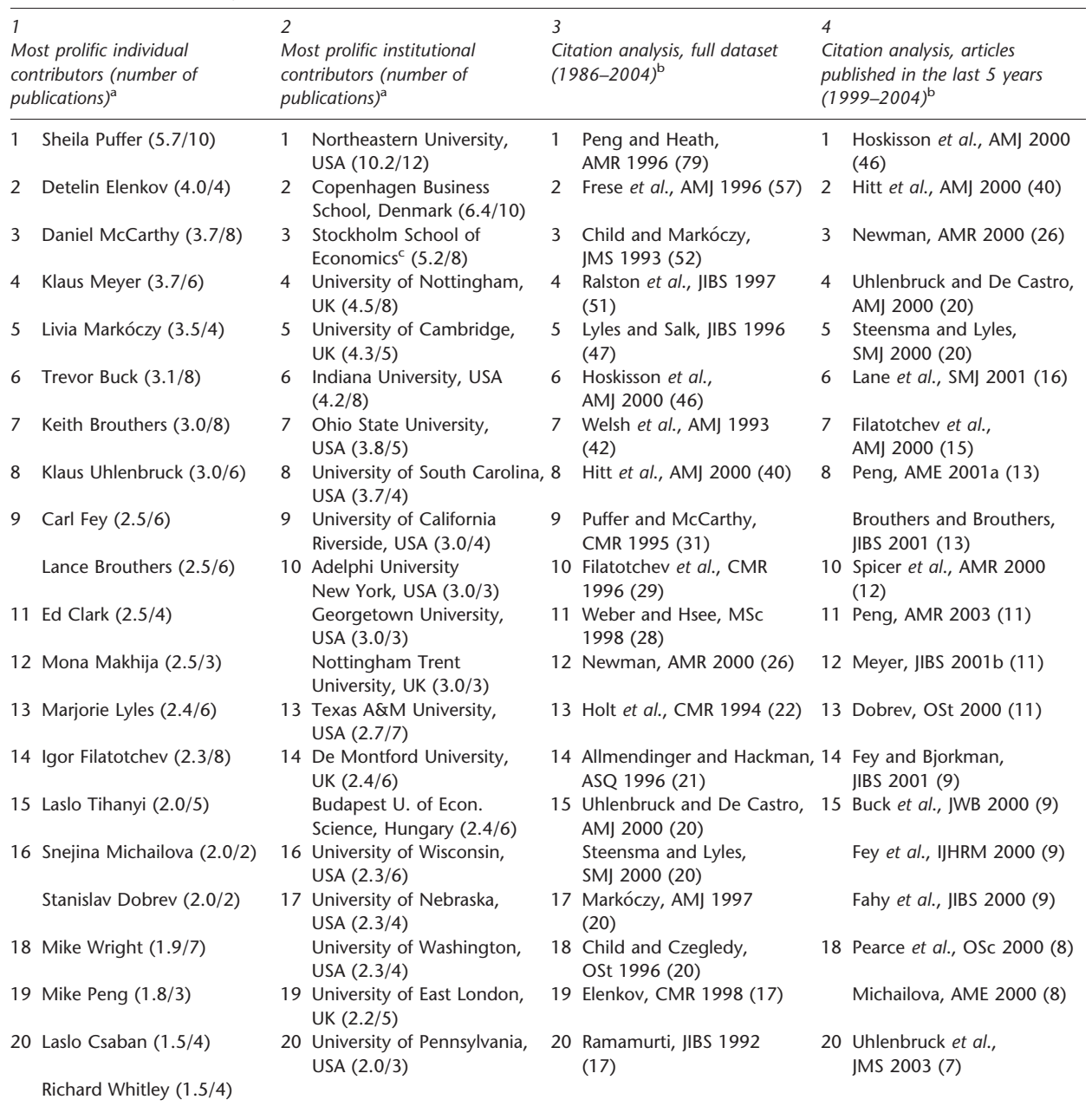

a Based on 218 publications in 13 top IB and management journals published during 1986-2004 (inclusive). These journals are the Academy of Management Journal, Academy of Management Review, Administrative Science Quarterly, International Business Review, Journal of Business Research, Journal of International Business Studies, Journal of International Management, Journal of Management Studies, Journal of World Business, Management International Review, Organization Science, Organization Studies, and Strategic Management Journal. The first number is 'adjusted' giving partial credit for all coauthored papers, and the second number refers to an author's total number of articles. See Lu (2003) and Peng (2001b) for details of this method. ${ }^{b}$ Number of citations in parentheses, as of 31 December 2004, according to the Social Sciences Citation Index.

'Stockholm School of Economics includes faculty of both campuses in Sweden and Russia.

(2000: 46 citations), Johnson and Loveman (1996: 23), Meyer (1998: 23), Estrin et al. (1997: 19), and Antal-Mokos (1998: 18). However, because books are not clearly identified in SSCI, we are unable to provide exact citation counts for all relevant books. Finally, the SSCI database as well as our own 
database has a better coverage of US-based journals than of European or Asian journals. Notably, there is no CEE-based management journal included in the SSCI database. This probably leads to relatively stronger ratings for scholars cited in North American journals, compared with those who may be influential within the CEE region.

\section{About the authors}

Klaus E. Meyer (Ph.D., London Business School) is a professor of management at the University of Reading, and was formerly a professor of international business strategy at Copenhagen Business School, Denmark. His research on the strategies of multinational enterprises in emerging economies, especially Eastern Europe and East Asia, has been published in, among other places, Journal of International Business Studies, Journal of Management Studies and Journal of Comparative Economics. In 2004 he published, jointly with Saul Estrin, Invest- ment Strategies in Emerging Economies. This is his fourth paper published in JIBS.

Mike W. Peng (Ph.D., University of Washington) is a professor of global strategy at the University of Texas at Dallas, where he holds the university's first ever Provost's Distinguished Research Professorship. He was formerly an associate professor at the Fisher College of Business, The Ohio State University. He is the author of numerous articles and three books, including, most recently, Global Strategy (Thomson South-Western, 2006). He has served on the editorial boards of the Academy of Management Journal, Academy of Management Review, Journal of International Business Studies and Strategic Management Journal, as a guest editor for a Journal of Management Studies special issue, and as an editor for the Asia Pacific Journal of Management. This is his fifth contribution to JIBS. 